\title{
GAMBARAN PENGGUNAAN OBAT ANTIDIURETIK PADA PASIEN GAGAL JANTUNG DI RUANG RAWAT INAP RUMAH SAKIT TK. II PUTRI HIJAU KESDAM I/BBPERIODE JANUARI SAMPAI DENGANDESEMBER TAHUN 2019
}

\author{
Robiatun Rambe ${ }^{1}$, Dwi Kumala Sari ${ }^{2 *}$ \\ ${ }^{1,2}$ Program Studi Farmasi, Fakultas Ilmu Kesehatan, Universitas Haji Sumatera Utara \\ Medan, Indonesia \\ Email: dewikumalasari565@yahoo.co.id \\ * corresponding author
}

\begin{abstract}
Abstrak
Gagal jantung merupakan keadaan patofisiologis ketika jantung sebagai pompa tidak mampu memenuhi kebutuhan darah untuk metabolisme jaringan. Penyakit gagal jantung harus mendapatkan perhatian agar tidak menimbulkan efek yang lebih parah lagi. Salah satu sediaan yang dapat menurunkan kejadian gagal jantung dengan pemberian diuretik. Penelitian ini bertujuan untuk mengidentifikasi obat antidiuretik dan presentase penggunaan antidiuretik yang paling sering diresepkan pada pasien gagal jantung di Ruang Rawat Inap Rumah Sakit Tk. II Putri Hijau Kesdam I/BB Periode Januari sampai dengan Desember 2019.Penelitian ini merupakan penelitian secara retrospektif. Penelitian ini telah dilaksanakan dengan mengambil data resep dari Januari 2019 sampai Desember 2019. Populasi dalam penelitian ini adalah sebanyak 115 pasien. Pengambilan sampel menggunakan Total sampling sehingga besar sampel adalah sebanyak 115 orang.Hasil Penelitian didapat yaitu Obat Antidiuretik untuk Pengobatan Gagal Jantung yang tersedia di Rumah Sakit Tk. II Putri Hijau adalah furosemide, hidrochlortiazid (CHT) dan spironolakton. Presentase Penggunaan Antidiuretik pada Pasien Gagal Jantung di Ruang Rawat Inap Rumah Sakit Tk. II Putri Hijau Kesdam I/BB Periode Januari sampai dengan Desember 2019 yang paling sering diresepkan adalah furosemide. Saran dalam penelitian ini diharapkan dengan adanya penelitian ini Rumah Sakit Tk. II Putri Hijau menjamin ketersediaan obat antidiuretik sebagai salah satu obat untuk penanganan gagal jantung karena dilihat tingkat kebutuhan pasien akan obat antidiuretik sangat tinggi.
\end{abstract}

Kata kunci: Diuretik, Obat antidiuretik, Penggunaan Obat antidiuretik

\begin{abstract}
Heart failure is a pathophysiological condition when the heart as a pump is unable to meet blood needs for tissue metabolism. Heart failure must get attention so that it does not have a more severe effect. One of the preparations that can reduce the incidence of heart failure by administering diuretics. This study aims to identify antidiuretic drugs and the percentage of use of antidiuretics that are most often prescribed to patients with heart failure in the Inpatient Room of the Tk Hospital. II Putri Hijau Kesdam I / BB Period January to December 2019.This study is a retrospective study. This study was conducted by taking prescription data from January 2019 to December 2019. The population in this study was 115 patients. Sampling using total sampling so that the sample size is as many as 115 people.The results of the study were that antidiuretic drugs
\end{abstract}


for the treatment of heart failure were available at the Tk. II Putri Hijau is furosemide, hidrochlortiazid (CHT) and spironolactone. Percentage of Antidiuretic Use in Heart Failure Patients in the Inpatient Room at Tk. II Putri Hijau Kesdam I / BB from January to December 2019 the most frequently prescribed is furosemide. Suggestions in this study are expected with this research Tk Hospital. II Putri Hijau guarantees the availability of antidiuretic drugs as one of the drugs for treating heart failure because it is seen that the patient's need for antidiuretic drugs is very high.

Keywords: Duiretic, antiduiretic drugs, Use of antidiuretic Drugs

\section{Pendahuluan}

Gagal jantung merupakan keadaan patofisiologis ketika jantung sebagai pompa tidak mampu memenuhi kebutuhan darah untuk metabolisme jaringan.Penyebab utama gagal jantung meliputi abnormalitas miokardium, overload beban luar, abnormalitas katup jantung, ritme jantung yang abnormal (aritmia), kegagalan terkait perikardium, dan kelainan kongenital deformitas jantung (Suryajaya, 2014).Penyakit gagal jantung harus mendapatkan perhatian agar tidak menimbulkan efek yang lebih parah lagi.Salah satu sediaan yang dapat menurunkan kejadian gagal jantung dengan pemberian diuretik.Diuretik biasanya digunakan untuk menurunkan volume cairan ekstraseluler, khususnya pada penyakit yang berhubungan dengan edema.Sediaan diuretik yang ideal seyogyanya mampu meningkatkan eksresi volume urin, eksresi natrium dan kalium (Andriyanto dkk, 2013).Gejala Gagal Jantung ditandai dengan sesak nafas pada saat beraktivitas maupun tidur, kelelahan, dan mengalami retensi cairan yang menimbulkan udem paru.Gejala ini harus diatasi dengan cepat melalui tindakan pengobatan yang komprehensif (Wulandari dkk, 2018).

Berdasarkan presentase pasien dengan penyakit gagal jantung yang diberikan antidiuretik pada Tahun 2020 adalah sebanyak 115 orang. Pasien gagal jantung perlu diperhatikan untuk mencegah komplikasi lain. Berdasarkan data golongan obat gagal jantung yang tersedia di Rumah Sakit Tk.II Putri Hijau yaitu seperti obat golongan angiotensin converting enzyme inhibitor (ACEI) atau angiotensin receptor blocker (ARB), dan obat diuretik seperti furosemid, hidrochlortiazid (CHT) dan spironolakton (Profil Rumah Sakit Putri Hijau, 2020).

Berdasarkan permasalahan diatas peneliti tertarik ingin melakukan penelitian tentang "Gambaran Penggunaan Obat Antidiuretik pada Pasien Gagal Jantung di Ruang Rawat Inap Rumah Sakit Tk. II Putri Hijau Kesdam I/BB Periode Januari sampai dengan Desember 2019".

\section{MetodePenelitian}

Jenis penelitian ini merupakan penelitian deskriptif yang pengumpulan data secara retrospektif yaitu penelitian berdasarkan rekam medis pasien dengan melihat kebelakang peristiwa yang terjadi di masa lalu berdasarkan data diambil yaitu Penggunaan Obat Antidiuretik pada pasien Gagal Jantung Periode Januari 2019 sampai dengan Desember 2019 pada pasien di Rumah Sakit Tk. II Putri Hijau Kesdam I/BB.Teknik pengambilan sampel menggunakan Total sampling.Penelitian ini telah dilaksanakan dengan mengambil data rekam medis periode Januari sampai dengan Desember 2019. Populasi dalam penelitian ini adalah seluruh pasien gagal jantung yang dirawat di Rumah Sakit Tk. II Putri Hijau Kesdam I/BB pada Periode Bulan Januari sampai dengan Desember 2019 
sebanyak 115 pasien. Data yang digunakan adalah data sekunder yaitu data yang diperoleh rekam medik pasien gagal jantung yang dirawat di Rumah Sakit Tk. II Putri Hijau Kesdam I/BB yang diberi informasi tentang jenis kelamin pasien, umur pasien, nama obat, golongan obat, dan dosis.Data yang diperoleh dianalisis secara deskriptif untuk mengetahui Gambaran Penggunaan Obat Antidiuretik pada Pasien Gagal Jantung di Ruang Rawat Inap Rumah Sakit Tk. II Putri Hijau Kesdam I/BB Periode Januari sampai dengan Desember 2019 yang meliputi pemberian obat diuretik seperti furosemid, hidrochlortiazid (CHT) dan spironolakton.

\section{Hasil dan Pembahasan}

Tabel 1. Obat Antidiuretik yang tersedia di Rumah Sakit Tk. II Putri Hijau

\begin{tabular}{cc}
\hline No & Nama Obat \\
\hline 1 & Furosemide \\
\hline 2 & Hidrochlortiazid $(\mathrm{CHT})$ \\
\hline 3 & Spironolakton \\
\hline
\end{tabular}

Berdasarkan tabel diatas dapat dilihat bahwa Obat Antidiuretik untuk Pengobatan Gagal Jantung yang tersedia di Rumah Sakit Tk. II Putri Hijau adalah furosemide, hidrochlortiazid (CHT) dan spironolakton.

Tabel 2. Profil Pasien berdasarkan Umur

\begin{tabular}{|c|c|c|c|c|c|c|c|c|c|c|c|c|c|c|c|}
\hline \multirow{3}{*}{ No } & \multirow{3}{*}{ Bln } & \multicolumn{12}{|c|}{ Umur } & & \\
\hline & & \multicolumn{2}{|c|}{$\begin{array}{c}<30 \\
\text { Tahun }\end{array}$} & \multicolumn{2}{|c|}{$\begin{array}{c}\text { 31-40 } \\
\text { Tahun }\end{array}$} & \multicolumn{2}{|c|}{$\begin{array}{c}41-50 \\
\text { Tahun }\end{array}$} & \multicolumn{2}{|c|}{$\begin{array}{c}51-60 \\
\text { Tahun }\end{array}$} & \multicolumn{2}{|c|}{$\begin{array}{c}61-70 \\
\text { Tahun }\end{array}$} & \multicolumn{2}{|c|}{$\begin{array}{c}>71 \\
\text { Tahun }\end{array}$} & \multicolumn{2}{|c|}{ Total } \\
\hline & & $\mathbf{F}$ & $\%$ & $\mathbf{F}$ & $\%$ & $\mathbf{F}$ & $\%$ & $\mathbf{F}$ & $\%$ & $\mathbf{F}$ & $\%$ & $\mathbf{F}$ & $\%$ & $\mathbf{F}$ & $\%$ \\
\hline 1 & Jan & 0 & 0 & 0 & 0 & 0 & 0 & 2 & 1,7 & 1 & 0,9 & 6 & 5,2 & 9 & 7,8 \\
\hline 2 & Feb & 0 & 0 & 0 & 0 & 3 & 2,6 & 1 & 0,9 & 4 & 3,5 & 0 & 0 & 8 & 7 \\
\hline 3 & Mar & 0 & 0 & 1 & 0,9 & 1 & 0,9 & 1 & 0,9 & 3 & 2,6 & 3 & 2,6 & 9 & 7,8 \\
\hline 4 & Apr & 0 & 0 & 0 & 0 & 1 & 0,9 & 3 & 2,6 & 3 & 2,6 & 3 & 2,6 & 10 & 8,7 \\
\hline 5 & Mei & 0 & 0 & 0 & 0 & 2 & 1,7 & 3 & 2,6 & 5 & 4,3 & 1 & 0,9 & 11 & 9,6 \\
\hline 6 & Juni & 0 & 0 & 0 & 0 & 2 & 1,7 & 3 & 2,6 & 2 & 1,7 & 2 & 1,7 & 9 & 7,8 \\
\hline 7 & Juli & 1 & 0,9 & 0 & 0 & 0 & 0 & 2 & 1,7 & 2 & 1,7 & 2 & 1,7 & 7 & 6,2 \\
\hline 8 & Agt & 1 & 0,9 & 0 & 0 & 0 & 0 & 1 & 0,9 & 5 & 4,3 & 2 & 1,7 & 9 & 7,8 \\
\hline 9 & Sept & 0 & 0 & 0 & 0 & 2 & 1,7 & 1 & 0,9 & 3 & 2,6 & 3 & 2,6 & 9 & 7,8 \\
\hline 10 & Okt & 1 & 0,9 & 0 & 0 & 0 & 0 & 3 & 2,6 & 2 & 1,7 & 3 & 2,6 & 9 & 7,8 \\
\hline 11 & Nop & 0 & 0 & 1 & 0,9 & 1 & 0,9 & 3 & 2,6 & 2 & 1,7 & 4 & 3,5 & 11 & 9,7 \\
\hline 12 & Des & 0 & 0 & 0 & 0 & 0 & 0 & 3 & 2,6 & 9 & 7,8 & 2 & 1,7 & 14 & 12 \\
\hline \multicolumn{2}{|c|}{ Total } & 3 & 2,6 & 2 & 1,7 & 12 & 10,4 & 26 & 22,6 & 41 & 35,7 & 31 & 27 & 115 & 100 \\
\hline
\end{tabular}

Berdasarkan tabel diatas dapat dilihat bahwa dari 115 orang pasien gagal jantung yang mendapatkan antidiuretik pada periode Januari 2019 sampai dengan Desember 2019 sebagian besar adalah usia 61-70 Tahun sebanyak 41 orang $(35,7 \%)$. Kemudian data penjabaran pemberian antidiuretik berdasarkan umur yaitu pada bulan Januari 2019 sebagian besar pasien usia >71 Tahun sebanyak 6 orang (5,2\%), bulan Februari 2019 sebagian besar pasien usia 61-70 Tahun sebanyak 4 orang (35\%), bulan Maret 2019 sebagian besar usia 61-70 tahun dan >71 Tahun dengan masing-masing sebanyak 3 orang (2,6\%), bulan April 2019 
sebagian besar pasien usia 51-60 Tahun, 61-70 Tahun dan >71 Tahun dengan masing-masing sebanyak 3 orang (2,6\%), bulan Mei 2019 sebagian besar pasien usia 61-70 Tahun sebanyak 5 orang (4,3\%), bulan Juni 2019 sebagian besar pasien usia 51-60 Tahun sebanyak 3 orang (2,6\%), bulan Juli 2019 sebagian besar pasien usia 51-60 tahun, 61-70 Tahun dan >71 tahun dengan masing-masing sebanyak 2 orang (1,7\%), bulan Agustus 2019 sebagian besar pasien usia 61-70 Tahun sebanyak 5 orang (4,3\%), bulan September 2019 sebagian besar pasien usia 61-70 Tahun dan $>71$ Tahun dengan masing-masing sebanyak 3 orang $(2,6 \%)$, bulan Oktober 2019 sebagian besar pasien usia 51-60 Tahun dan >71 Tahun dengan masing-masing sebanyak 3 orang (2,6\%), bulan Nopember 2019 sebagian besar pasien usia $>71$ Tahun Tahun sebanyak 4 orang (3,5\%) dan bulan Desember 2019 sebagian besar pasien usia 61-70 Tahun sebanyak 9 orang $(7,8 \%)$.

Tabel 3.Profil Pasien berdasarkan Jenis Kelamin

\begin{tabular}{|c|c|c|c|c|c|c|c|}
\hline \multirow{3}{*}{ No } & \multirow{3}{*}{ Bulan } & \multicolumn{4}{|c|}{ Jenis Kelamin } & \multirow{2}{*}{\multicolumn{2}{|c|}{ Total }} \\
\hline & & \multicolumn{2}{|c|}{ Laki-Laki } & \multicolumn{2}{|c|}{ Perempuan } & & \\
\hline & & $\mathbf{F}$ & $\%$ & $\mathbf{F}$ & $\%$ & $\mathbf{F}$ & $\%$ \\
\hline 1 & Januari & 6 & 5,2 & 3 & 2,6 & 9 & 7,8 \\
\hline 2 & Februari & 5 & 4,3 & 3 & 2,7 & 8 & 7 \\
\hline 3 & Maret & 4 & 3,5 & 5 & 4,3 & 9 & 7,8 \\
\hline 4 & April & 2 & 1,7 & 8 & 7 & 10 & 8,7 \\
\hline 5 & Mei & 4 & 3,5 & 7 & 6,1 & 11 & 9,6 \\
\hline 6 & Juni & 6 & 5,2 & 3 & 2,6 & 9 & 7,8 \\
\hline 7 & Juli & 2 & 1,7 & 5 & 4,3 & 7 & 6,2 \\
\hline 8 & Agustus & 4 & 3,5 & 5 & 4,3 & 9 & 7,8 \\
\hline 9 & September & 3 & 2,6 & 6 & 5,2 & 9 & 7,8 \\
\hline 10 & Oktober & 2 & 1,7 & 7 & 6,1 & 9 & 7,8 \\
\hline 11 & Nopember & 6 & 5,2 & 5 & 4,3 & 11 & 9,7 \\
\hline 12 & Desember & 8 & 7 & 6 & 5,2 & 14 & 12 \\
\hline & Total & 52 & 45,2 & 63 & 54,8 & 115 & 100 \\
\hline
\end{tabular}

Berdasarkan tabel 4.3 diatas dapat dilihat bahwa dari 115 orang pasien gagal jantung yang mendapatkan antidiuretik pada periode Januari 2019 sampai dengan Desember 2019 sebagian besar adalah jenis kelamin perempuan sebanyak 63 orang $(54,8 \%)$. Kemudian data penjabaran pemberian antidiuretik berdasarkan jenis kelamin yaitu pada bulan Januari 2019 sebagian besar pasien adalah laki-laki sebanyak 6 orang $(5,2 \%)$, bulan Februari 2019 sebagian besar adalah laki-laki sebanyak 5 orang $(4,3 \%)$, bulan Maret 2019 sebagian besar adalah perempuan sebanyak 5 orang (4,3\%), bulan April 2019 sebagian besar adalah perempuan sebanyak 8 orang (7\%), bulan Mei 2019 sebagian besar adalah perempuan sebanyak 7 orang $(6,1 \%)$, bulan Juni 2019 sebagian besar adalah laki-laki sebanyak 6 orang $(5,2 \%)$, bulan Juli 2019 sebangian besar adalah perempuan sebanyak 5 orang $(71,4 \%)$, bulan Agustus 2019 sebagian besar adalah perempuan sebanyak 5 orang $(55,6 \%)$, bulan September 2019 sebagian besar adalah perempuan sebanyak 6 orang $(5,2 \%)$, bulan Oktober 2019 sama adalah perempuan sebanyak 7 orang $(6,1 \%)$, bulan Nopember 2019 sebagian besar adalah lakilakisebanyak 6 orang (52\%) dan bulan Desember 2019 sebagian besar adalah lakilaki sebanyak 8 orang $(7 \%)$. 
Tabel 4. Distribusi Frekuensi Presentase Penggunaan Obat Antihipertensi di Puskesmas Tangkahan Durian Periode Bulan Januari 2019 sampai dengan Bulan Desember 2019

\begin{tabular}{|c|c|c|c|c|c|c|c|c|c|}
\hline \multirow{3}{*}{ No } & \multirow{3}{*}{ Bulan } & \multicolumn{6}{|c|}{ Penggunaan Obat } & \multirow{2}{*}{\multicolumn{2}{|c|}{ Total }} \\
\hline & & \multicolumn{2}{|c|}{$\begin{array}{c}\text { Amlodipine } 10 \\
\text { mg }\end{array}$} & \multicolumn{2}{|c|}{$\begin{array}{c}\text { Captopril } 25 \\
\text { mg }\end{array}$} & \multicolumn{2}{|c|}{$\begin{array}{c}\text { Nifedipiner } 10 \\
\text { mg }\end{array}$} & & \\
\hline & & $\mathbf{F}$ & $\%$ & $\mathbf{F}$ & $\%$ & $\mathbf{F}$ & $\%$ & $\mathbf{F}$ & $\%$ \\
\hline 1 & Januari & 28 & 47,5 & 17 & 28,8 & 14 & 23,7 & 59 & 100 \\
\hline 2 & Februari & 19 & 44,2 & 14 & 32,5 & 10 & 23,3 & 43 & 100 \\
\hline 3 & Maret & 18 & 42,8 & 15 & 35,7 & 9 & 21,5 & 42 & 100 \\
\hline 4 & April & 24 & 42,1 & 21 & 36,8 & 12 & 21,1 & 57 & 100 \\
\hline 5 & Mei & 18 & 40 & 15 & 33,3 & 12 & 26,7 & 45 & 100 \\
\hline 6 & Juni & 22 & 41,5 & 18 & 33,9 & 13 & 24,6 & 53 & 100 \\
\hline 7 & Juli & 18 & 38,3 & 15 & 31,9 & 14 & 29,8 & 47 & 100 \\
\hline 8 & Agustus & 18 & 37,5 & 17 & 35,4 & 13 & 27,1 & 48 & 100 \\
\hline 9 & September & 20 & 37,7 & 17 & 32,1 & 16 & 30,2 & 53 & 100 \\
\hline 10 & Oktober & 17 & 40,5 & 13 & 30,9 & 12 & 28,6 & 42 & 100 \\
\hline 11 & Nopember & 19 & 38 & 16 & 32 & 15 & 30 & 50 & 100 \\
\hline 12 & Desember & 17 & 38,6 & 15 & 34,1 & 12 & 27,3 & 44 & 100 \\
\hline & Total & 238 & 40,8 & 193 & 33,1 & 152 & 26,1 & 583 & 100 \\
\hline
\end{tabular}

Berdasarkan tabel diatas dapat dilihat bahwa Presentase Penggunaan Antidiuretik pada Pasien Gagal Jantung di Ruang Rawat Inap Rumah Sakit Tk. II Putri Hijau Kesdam I/BB Periode Januari sampai dengan Desember 2019 yang paling sering diresepkan adalah furosemide sebanyak 62 kali diresepkan $(53,9 \%)$ dengan distribusi pada bulan Januari 2019 sebanyak 5 resep (4,3\%), bulan Februari 2019 sebanyak 4 resep (3,5\%), bulan Maret 2019 sebanyak 4 resep (3,5\%), bulan April 2019 sebanyak 5 resep (4,3\%), bulan Mei 2019 sebanyak 8 resep (7\%), bulan Juni 2019 sebanyak 5 resep (4,3\%), bulan Juli 2019 sebanyak 4 resep (3,5\%), bulan Agustus 2019 sebanyak 5 resep (4,3\%), bulan September 2019 sebanyak 4 resep $(3,5 \%)$, bulan Oktober 2019 sebanyak 5 resep (4,3\%), bulan Nopember 2019 sebanyak 6 resep (5,2\%) dan bulan Desember 2019 sebanyak 7 resep $(6,1 \%)$.

\section{Kesimpulan}

Berdasarkan penelitian yang dilakukan di Puskesmas Tangkahan Durian dapatdisimpulkan sebagai berikut : Presentase penggunaan Furosemide untuk Pengobatan Gagal Jantung yang tersedia di Rumah Sakit Tk. II Putri Hijau adalah sebesar 53,9\%.Presentase penggunaan Hidrochlortiazid (CHT) untuk Pengobatan Gagal Jantung yang tersedia di Rumah Sakit Tk. II Putri Hijau adalah sebesar 24,3\%. Presentase penggunaan Spironolakton untuk Pengobatan Gagal Jantung yang tersedia di Rumah Sakit Tk. II Putri Hijau adalah sebesar 21,8\%. Dan presentase Penggunaan Antidiuretik pada Pasien Gagal Jantung di Ruang Rawat Inap Rumah Sakit Tk. II Putri Hijau Kesdam I/BB Periode Januari sampai dengan Desember 2019 yang paling sering diresepkan adalah furosemide sebesar $53,9 \%$. 


\section{Referensi}

Andriyanto, Poniman, Sutisna, A dan Manalu, W. (2013). Evaluasi Aktivitas Diuretik Ekstrak Etanol Buah Belimbing Wuluh (Averrhoa bilimbi) sebagai Diuretik Alami : Kadar Natrium, Kalium dan pH Urin. Jurnal Ilmu Kefarmasian Indonesia. Volume 11. Nomor 1. ISSN : 1693-1831

Hidayat, S. S. dkk. (2015). Panduan Penulisan Skripsi Sarjana, Edisi Revisi - Juli 2015. Bandung : Fakultas Psikologi Universitas Kristen Maranatha

Idzni, N,F. (2017). Studi Potensi Interaksi Obat pada Terapi Pasien Gagal Jantng di instalasi Rawat Inap RSUD Jombang Tahun 2016. Skripsi. Universitas Islam negeri Maulana Malik Ibrahim malang.

Kemenkes RI. (2019). Hari Jantung Sedunia (HJS) Tahun 2019 : Jantung Sehat, SDM Unggul. Kemenkes RI. Jakarta.

Lupiyatama, S. (2012). Gambaran Peresepan Digoksin Pada Pasien Gagal Jantung Yang Berobat Jalan Di RSUP Dr. Kariadi semarang.

Makani, M dan Setyaningrum, N. (2017). Pola Penggunaan Furosemide dan Perubahan Elektrolit Pasien Gagal Jantung di Rumah Sakit X Yogyakarta. Jurnal Ilmiah Farmasi. ISSN : 1693-8666

Mycek, M.J.; Harvey, R.A. dan Champe C.C. (2011). Farmakologi Ulasan Bergambar. Edisi IV. Terjemah oleh Azwar Agoes. 2014. Jakarta: Widya Medika

Notoatmodjo, Soekidjo. (2014). Promosi Kesehatan dan Perilaku Kesehatan, Rineka Cipta, Jakarta

Notoatmodjo. (2010). Metodologi Penelitian Kesehatan. Jakarta : PT. Rineka Cipta

Nurjannah, N. D. (2019). Gambaran Kepatuhan Pasien Gagal Jantung dalam Melakukan Managemen Pengobatan di RSUD Dr. Moewardi Surakarta. Skripsi. Universitas Muhammadiyah Surakarta.

Nursalam. (2016). Metodologi Penelitian Ilmu Keperawatan: Pendekatan Praktis. Ediisi 3. Jakarta. Salemba Medika.

Page RL dan Lindenfeld J. (2012). The comorbidity conundrum: a focus on the role of noncardiovascular chronic conditions in the heart failure patient. Curr Cardiol Rep. 14:276-284

Profil Rumah Sakit Tk. II Putri Hijau. (2020). Data Rekam Medis Pasien Gagal Jantung.

Rich, MW. (2012). Pharmacotherapy of heart failure in the elderly: adverse events. Heart Fail Rev. 17:589-595.

Saepudin. (2015). Antagonis Reseptor Arginine Vasopressin : Harapan Baru dalam Penanganan Hiponatremia pada Pasien Gagal Jantung. Jurnal Farmasi Klinik Indonesia. Volume 2. Nomor 2. DOI : 10.15416/ijcp.2015.4.2.129

Sistha, F. N. (2013). Gambaran Dan Analisis Biaya Pengobatan Gagal Jantung Kongestif Pada Pasien Rawat Inap di RS “A” di Surakarta Tahun 2011. Skripsi. Fakultas Farmasi Universitas Muhammadiyah Surakarta.

Sujarweni, V. Wiratna. (2014). Metode Penelitian: Lengkap, Praktis, dan Mudah Dipahami. Yogyakarta: Pustaka Baru Press

Suryajaya, C. (2014). Gambaran Peresepan Beta Bloker pada Pasien Gagal Jantung yang Dirawat Inap di RSUP Dr. Kariadi Semarang Periode Januari-Desember 2013. Karya Tulis Ilmiah. Universitas Diponegoro.

Tariq, Sohaib dan Wilbert S. Aronow. (2015). Use of Inotropic Agents in Treatment of Systolic Heart Failure. International Journal of Molecular Science. Vol. 16: 29060-29068

WHO. World Health Statistic Report. (2015). Geneva: World Health Organization; 2015. WHO. (2014). The atlas Heart Disease and Stroke. Volume 84. WHO. New York. 
Wulandari, T, Nurmainah dan Robiyanto. (2018). Gambaran Penggunaan Obat pada Pasien Gagal Jantung Kongestif Rawat Inap di Rumah sakit Sultan Syarif Mohamad Alkadrie Pontianak. Program Studi Farmasi Fakultas Kedokteran universitas Tanjungpura Pontianak. 